\title{
Changes in local oceanographic and atmospheric conditions shortly after the 2004 Indian Ocean tsunami
}

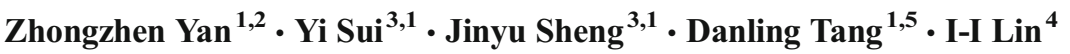

Received: 28 October 2014 / Accepted: 3 April 2015 /Published online: 21 April 2015

(C) The Author(s) 2015. This article is published with open access at Springerlink.com

\begin{abstract}
This study examines changes in the local oceanographic and atmospheric conditions over the southern Bay of Bengal and adjacent Indian Ocean waters after the 2004 Indian Ocean tsunami based on satellite remote sensing data and atmospheric reanalysis fields. After the tsunami that occurred on 26 December 2004, the accumulated rainfall had a notably increase (600 mm per month) in January of 2005 over deep waters to the southeast of Sri Lanka. This rainfall increase after the tsunami was accompanied with cooling in the sea surface temperature (SST) (up to $-2{ }^{\circ} \mathrm{C}$ ). Four-day averaged SST anomalies had a noticeable increase $\left(1-4^{\circ} \mathrm{C}\right)$ after the tsunami over the deep waters to the southwest of the epicenter. Series of ocean atmospheric and biological variables changed successively after the
\end{abstract}

Responsible Editor: Tal Ezer

This article is part of the Topical Collection on the 6th International Workshop on Modeling the Ocean (IWMO) in Halifax, Nova Scotia, Canada 23-27 June 2014

Danling Tang

lingzistdl@126.com

1 Research Center of Remote Sensing and Marine Ecology \& Environment (RSMEE), State Key Laboratory for Tropical Environment, South China Sea Institute of Oceanology, Chinese Academy of Sciences, Guangzhou 510301, People's Republic of China

2 State Key Laboratory of Estuarine and Coastal Research, East China Normal University, Shanghai, China

3 Department of Oceanography, Dalhousie University, Halifax, Nova Scotia, Canada

4 Department of Atmospheric Sciences, National Taiwan University, Taipei, Taiwan

5 Collaborative Innovation Center for 21st-Century Maritime Silk Road Studies, Guangzhou, China change of SST. The chain of causality between the tsunami and the changes in the local atmospheric conditions is suggested.

Keywords Indian Ocean · Tsunami - Sea surface temperature $\cdot$ Rainfall $\cdot$ Wind

\section{Introduction}

The atmosphere and ocean act as one interdependent system and are coupled by complicated feedback components (Thurman and Trujillo 2002). Tropical cyclones, for example, obtain their energy from the evaporation of water from the ocean surface and eventually recondense into clouds and rain when the moist air rises and cools to saturation. In addition to strong winds and heavy rain, tropical cyclones are capable of generating severe surface waves, large storm surge, and tornadoes.

The 2004 Indian Ocean tsunami is the greatest tsunami in the past 100 years (Yan and Tang 2009). This tsunami was caused by the Sumatra-Andaman earthquake, which is an undersea megathrust earthquake that occurred at 00:58:53 Coordinated Universal Time (UTC) on 26 December 2004, with an epicenter off the west coast of Sumatra, Indonesia (Lay et al. 2005). The Indian Ocean tsunami resulted in catastrophic losses of over 230,000 human lives and massive damage to housing, utilities, roads, and bridges in 12 countries around the Indian Ocean (Lay et al. 2005; UNEP 2005). Previous studies suggested that this tsunami might also have long-lasting effects on chemical, physical, biological, and ecological conditions in the Bay of Bengal and adjacent waters (DOD 2005; UNEP 2005; Tang et al. 2006, 2008; Agarwal et al. 2007; Luis et al. 2007; Singh et al. 2007; Yan and Tang 2009). Due to large displacement and strong vertical mixing of the ocean water caused by this tsunami, some physical and chemical variables of the ocean water, such as the sea surface 
temperature (SST), salinity, dissolved oxygen, and nutrients exhibited post-tsunami changes in the northern Indian Ocean (Anilkumar et al. 2006; Luis et al. 2007; Agarwal et al. 2007; Yan and Tang 2009; Tang et al. 2006). SST variations exceeding $1{ }^{\circ} \mathrm{C}$, for example, were observed after the tsunami in water columns between 50 and $250 \mathrm{~m}$ over areas to the west of Andaman Islands (Luis et al. 2007; Agarwal et al. 2007). The upper ocean thermocline structure in the Bay of Bengal (BoB) was modified after the tsunami with the surface mixed layer thickness reduced by 10 to $30 \mathrm{~m}$, due mainly to the tsunamiinduced vertical entrainment (Luis et al. 2007). The tsunamiinduced ocean waves stirred up sediments over coastal regions and increased suspended sediment concentrations ( $\mathrm{SSCs}$ ) in the northeastern Indian Ocean (Anilkumar et al. 2006). Because of the detrimental effects of the tsunami on the riverbank and coastal vegetation, the SSC in the coastal waters showed increases in the wet season of 2005 (Yan and Tang 2009). The increase of suspended sediments may absorb or scatter the solar irradiance and reduce its transmissivity, thereafter severely impacting the marine primary production (Tang et al. 2006).

The 2004 Indian Ocean tsunami also modulated the local atmospheric conditions. It was reported that both the water vapor loading and winds in the boundary layer of the $\mathrm{BoB}$ were affected by this tsunami (Agarwal et al. 2007). Abnormal changes of atmospheric conditions, such as a decrease in the sea level air pressure by $0.6 \mathrm{hPa}$, an increase in the relative humidity by $30 \%$, and a prominent reduction in the air temperature by more than $3{ }^{\circ} \mathrm{C}$ on the day of the tsunami along the Indian coasts, were also observed on 26 December 2004 (Vishnu et al. 2012). Using an eddy-viscosity model for the averaged Reynolds stresses in turbulent flow, Godin (2004) examined theoretically the interaction of a tsunami in the deep ocean with a turbulent wind under neutral stratified atmospheric conditions and demonstrated that in the lowest tens of centimeters of the atmosphere, tsunami-induced perturbations of winds are much greater than the perturbations in ocean currents. Large tsunami-induced changes in the surface winds and SST should also modify the latent heat flux at the sea surface. The latent heat flux (LHF) is the flux of heat between the Earth's surface (including the sea surface) and the atmosphere and is associated with evaporation or evapotranspiration of water at the surface, leading to energy transfer to the atmosphere and subsequent condensation of water vapor and release of that energy in the troposphere. Therefore, high winds and large temperature differences between the atmosphere and the Earth's surface should lead to high LHF (Liu 1988). The tsunami-enhanced turbulent vertical mixing should also affect the air-sea heat exchange and the ocean surface boundary layer properties (Agarwal et al. 2007).

It should be noted that most of previous studies on the effects of the 2004 Indian Ocean tsunami on the physical oceanographic conditions in the northern Indian Ocean were based on sparse in situ temperature and salinity measurements at a few stations. In particular, the post-tsunami effect on the SST was studied mainly around Andaman and Nicobar Islands and in some coastal areas of the BoB (Murthy 2005; Agarwal et al. 2007). Furthermore, the posttsunami effects on the local atmospheric conditions such as wind and rainfall remain to be studied. The main objective of this study is to examine the effects of the 2004 Indian Ocean tsunami on the local atmospheric and oceanographic conditions in the southern BoB and adjacent Indian Ocean waters based on the satellite remote sensing data and atmospheric reanalysis fields. The remainder of this paper is organized as follows. Section 2 presents the data and methods used in this study. Section 3 discusses results, and section 4 is discussion.

\section{Study region, data, and methods}

\subsection{Study region}

The study region is the southern $\mathrm{BoB}$ and adjacent deep waters of the northern Indian Ocean between $2^{\circ} \mathrm{S}$ and $10^{\circ} \mathrm{N}$ and between $78^{\circ} \mathrm{E}$ and $98^{\circ} \mathrm{E}$ (Fig. 1). The BoB is the largest bay in the world by area. It covers $\sim 2.17 \times 10^{6} \mathrm{~km}^{2}$, with a maximum width of $\sim 1000 \mathrm{~km}$ around $15^{\circ} \mathrm{N}$ (Sarma et al. 2000). The BoB is a semi-enclosed basin bordered by Sri Lanka and India to the west, Bangladesh to the north, and Myanmar and the northern part of the Malay Peninsula and Sumatra Island to the east. The mean water depth in the bay is $\sim 2600 \mathrm{~m}$ with a maximum depth of $\sim 5260 \mathrm{~m}$. The central part of the BoB is comparatively flat with water depths increasing from $\sim 2500 \mathrm{~m}$ over the northern part to $\sim 3800 \mathrm{~m}$ over the southern part of the bay.

The local climate of the BoB is dominated by monsoons. From November to April, the northeast (winter) monsoon prevails, with northeasterly winds blowing from the high atmospheric pressure area over the Asian continent into the north of the bay (Potemra et al. 1991). From June to September, by comparison, the rain-bearing southwest (summer) monsoon prevails, and intense heat produces a low-pressure system over the continent and a subsequent airflow from the ocean. The hydrographic conditions in the bay are determined largely by the monsoon winds and hydrographic characteristics of deep waters in the Indian Ocean. Freshwater discharge from rivers in the region affects the hydrodynamics over the northern part of the bay, with a freshwater plume along the Indian coast during the southwest monsoon (Vinayachandran and Kurian 2007). The main oceanic surface circulation in the $\mathrm{BoB}$ in the winter monsoon from December to March is characterized by an anticyclonic circulation over the northern part, broad southward or southwestward currents over the southern part, and strong southward jet along the east coast of Sri Lanka (Paul et al. 2009; Kumar and 


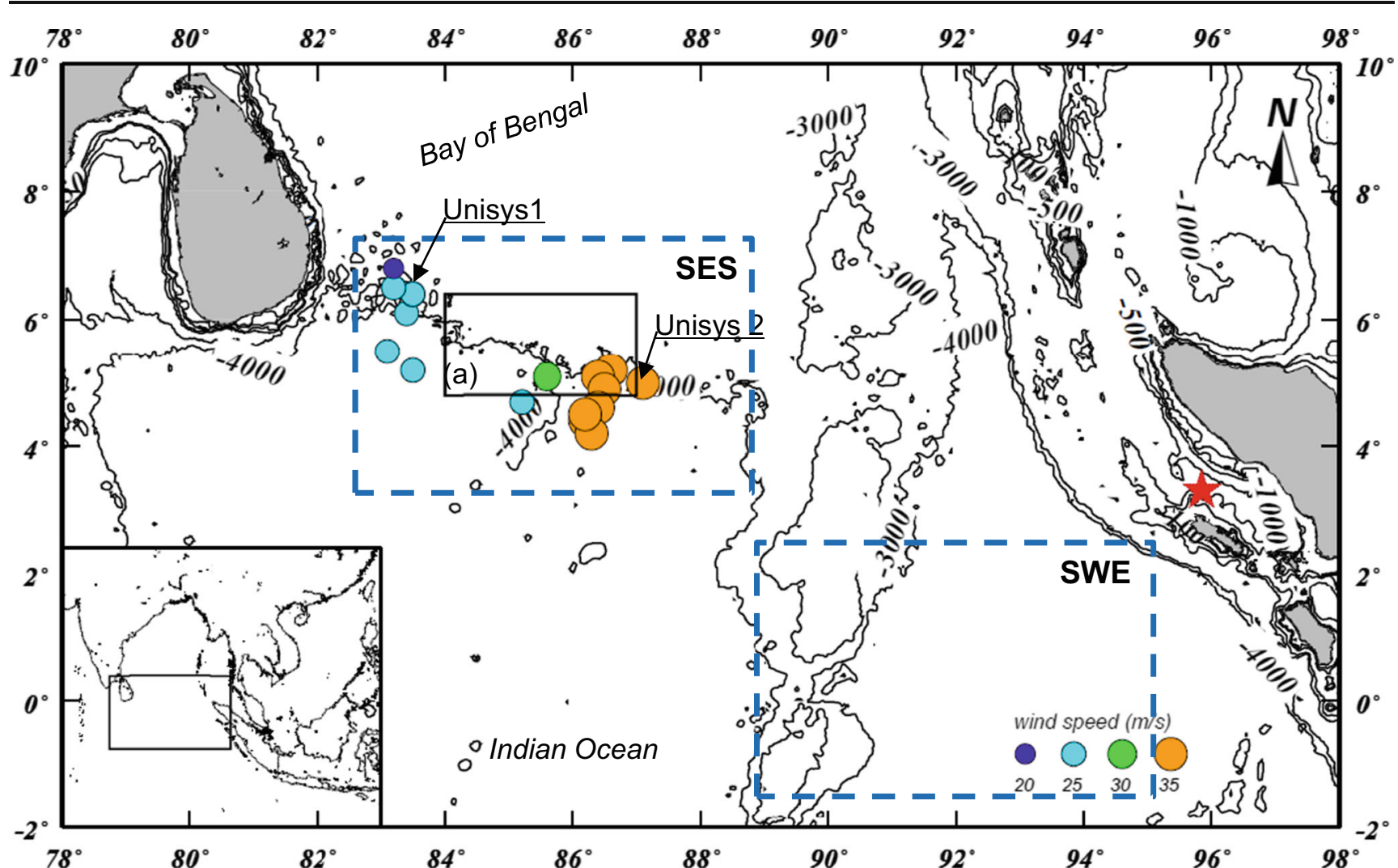

Fig. 1 Major bathymetric features of the southern Bay of Bengal and adjacent waters in the northern Indian Ocean. Inset over the lower left corner of the figure shows the study region in the northern Indian Ocean. Colored cycle symbols represent positions and speeds of two tropical storms known as Unisys 1 and 2 which swept the offshore area to the

southeast of Sri Lanka. The satellite data and atmospheric reanalysis data over the small area marked by a solid box are discussed in the paper. Two large areas marked by dashed boxes are referred to as the area to the southeast of Sri Lanka (SES) and the area to the southwest of the epicenter (SWE)

Chakraborty 2011). In the summer monsoon from June to August, the general oceanic surface circulation in the BoB is characterized by a small-size cyclonic gyre over the northern part, broad southeastward currents over the central part, and strong eastward currents over the south part of the bay.

The epicenter of the 9.3-magnitude Sumatra-Andaman earthquake occurred at about $1300 \mathrm{~km}$ of the oceanic subduction zone at about $100 \mathrm{~km}$ to the west of Sumatra and Nicobar and Andaman Islands (Titov et al. 2004). After this tsunami, two tropical storms with maximum speeds of $\sim 35 \mathrm{~km} \mathrm{~h}^{-1}$ swept the study region separately on 8-10 January (Unisys 1) and 14-17 January (Unisys 2) 2005 (http://weather.unisys.com/). It is unknown whether these two tropical storms had any succession relationship with the 2004 Indian Ocean tsunami.

In this study, time-series of satellite remote sensing data and atmospheric reanalysis data over a small area (between $84^{\circ} \mathrm{E}$ and $87^{\circ} \mathrm{E}$ and between $4.8^{\circ} \mathrm{N}$ and $6.4^{\circ} \mathrm{N}$ marked by the solid box in Fig. 1) to the southeast of Sri Lanka are used to examine changes in the oceanographic and atmospheric conditions before and after the tsunami. This area was chosen mainly based on its reasonable availability of the satellite remote sensing SST data.

\subsection{Satellite remote sensing data and atmospheric reanalysis products}

(a) Sea surface temperature

Time-series of daily mean global sea surface temperature (SST) products of the Moderate Resolution Imaging Spectroradiometer (MODIS, Level 3) are used in this study. The MODIS data with a spatial resolution of $9.26 \mathrm{~km}$ (mapped products) were derived from the MODIS sensors onboard the NASA Terra and Aqua platforms available since November 2000. The MODIS SST products used here were obtained from the Ocean Color Web (http://oceancolor.gsfc.nasa.gov).

(b) Sea surface heat flux, relative humidity, and sea level pressure

The daily latent heat flux (LHF), sensible heat flux (SHF), relative humidity, and sea level pressure fields at the sea surface were derived from the atmospheric reanalysis products produced by the National Center for Environmental Prediction (NCEP). The spatial 
resolution for the products is $2.5^{\circ} \times 2.5^{\circ}$, and the data were obtained from the website of the Physical Science Division at the Earth System Research Laboratory of the National Oceanic and Atmospheric Administration (PSD-ESRL/NOAA, http://www.cdc.noaa.gov).

(c) Precipitation

The satellite remote sensing data for precipitation were estimated from the three hourly products of the Tropical Rainfall Measuring Mission (TRMM, 3B42 V6 derived, Level 3). The spatial resolution for the TRMM products is $0.25^{\circ} \times 0.25^{\circ}$. The daily mean precipitation data computed from the three hourly TRMM products were obtained from the website of the Goddard Earth Sciences Data and Information Services Center (GES DISC, http://disc2.nascom.nasa.gov/ Giovanni/tovas).

(d) Sea surface wind

The sea surface wind fields over the study region were taken from the ocean surface wind products generated by the Quick Scatterometer (QuickSCat), which are available at the website for the Remote Sensing Systems sponsored by the NASA Ocean Vector Winds Science Team (http:/www.remss.com). The Level 3 QuickScat data were generated using the Direction Interval Retrieval with Threshold Nudging (DIRTH) method from the QuickScat Level 2B ocean surface wind data with a horizontal resolution of approximately $0.25^{\circ} \times 0$. $25^{\circ}$.

(e) Sea level anomaly

The near real-time sea level anomalies (SLAs) extracted from Ssalt/Duacs multimission altimeter products are used to examine the changes of sea level anomaly before and after the tsunami in this study. The SLA data were obtained from the website for Archiving, Validation, and Interpretation of Satellite Oceanographic data (AVISO) http://www.aviso.oceanobs.com).

\subsection{Data analysis method}

The 4-day means of satellite remote sensing fields for the SST, wind, and accumulated rainfall were computed from the daily mean fields for 71 days from 20 November 2004 to 30 January 2005 . The color images of 4-day means were constructed by the Grid Analysis and Display System (GrADS, v.1.8) for the study region shown in Fig. 1. The 4-day means of the MODIS SSTs, QuickScat wind speeds, and TRMM rainfall during ten selected periods are used to investigate the changes in the local atmospheric and oceanographic conditions in the study region associated with the Indian Ocean tsunami. Each period lasts 4 days. These ten selected periods are (1) 23-25 December, (2) 26-29 December, (3) 30 December-2 January, (4) 3-6 January, (5) 7-10 January, (6)
11-14 January, (7) 15-18 January, (8) 19-22 January, (9) 23-26 January, and (10) 27-30 January. The satellite data and reanalysis fields in the first period (23-25 December) are used to represent the atmospheric and oceanographic conditions before the tsunami. The data and fields in the remaining nine periods (26 December to 30 January) are used to represent the post-tsunami conditions. The 4-day means are considered in this study, due to the cloud cover which affects the availability of satellite remote sensing SST data.

\section{Results}

\subsection{Changes in the sea surface temperature and air temperature}

We first consider the general SST features inferred from the available MODIS SST data over the study region. The MODIS SST data coverage in the study region is very good during periods $2,3,8,9$, and 10 (Fig. 2a) but comparably poor during other periods, particularly in periods 4 and 5 due to the cloud cover. A comparison of SST images shown in Fig. 2a12 indicates that surface waters over the northern Indian Ocean to the southwest of the epicenter (SWE, see Fig. 2a2) got warmer by up to $4{ }^{\circ} \mathrm{C}$ during the first 4-day period after the Indian Ocean tsunami (from 26 to 29 December, 2004). The warm surface waters around the SWE area spread northward in the third period (30 December to 2 January, Fig. 2a3) due mainly to the northward surface currents, as evident from 4day mean surface currents shown in Fig. 3. The time-mean surface currents and SSTs shown in Fig. 3 were calculated from the three hourly fields extracted from the $1 / 12^{\circ}$-resolution global ocean reanalysis produced by the ocean circulation model known as the Hybrid Coordinate Ocean Model (HYCOM) using the Navy Coupled Ocean Data Assimilation (NCODA). The HYCOM+NCODA reanalysis (run GLBu0.08/expt_19.1) was carried out on the GLBb0.08 computational grid, and the output was served on the uniform GLBu0.08 grid. The surface forcing including wind stress and heat/freshwater fluxes was taken/calculated from hourly Climate Forecast System Reanalysis (CFSR) with a horizontal resolution of $0.3125^{\circ}$ produced by the National Centers for Environmental Prediction (NCEP). A reader is referred to the webpage for HYCOM at hycom.org/data/glbu0pt08/expt19pt1. It should be noted that the effect of the 2004 Indian Ocean tsunami was not explicitly considered in the numerical simulation for the HYCOM+NCODA reanalysis. Therefore, the 4-day mean fields of surface currents and SSTs presented in Fig. 3 are only for a general reference of surface circulation and hydrography in the study region.

Over the SWE area and adjacent areas, the surface currents are relatively strong and approximately northwestward during 
(a) MODIS SST
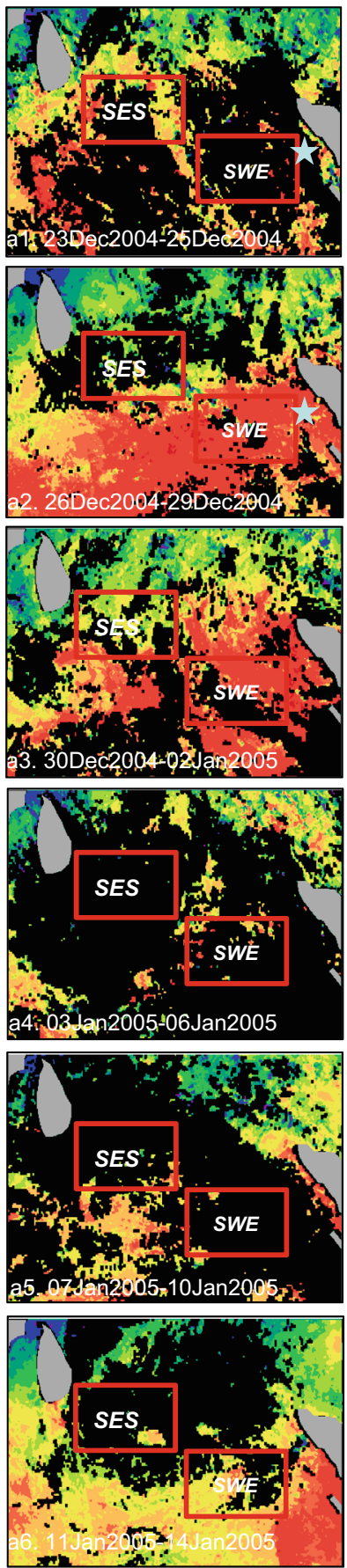

(b) Quick Scat Wind
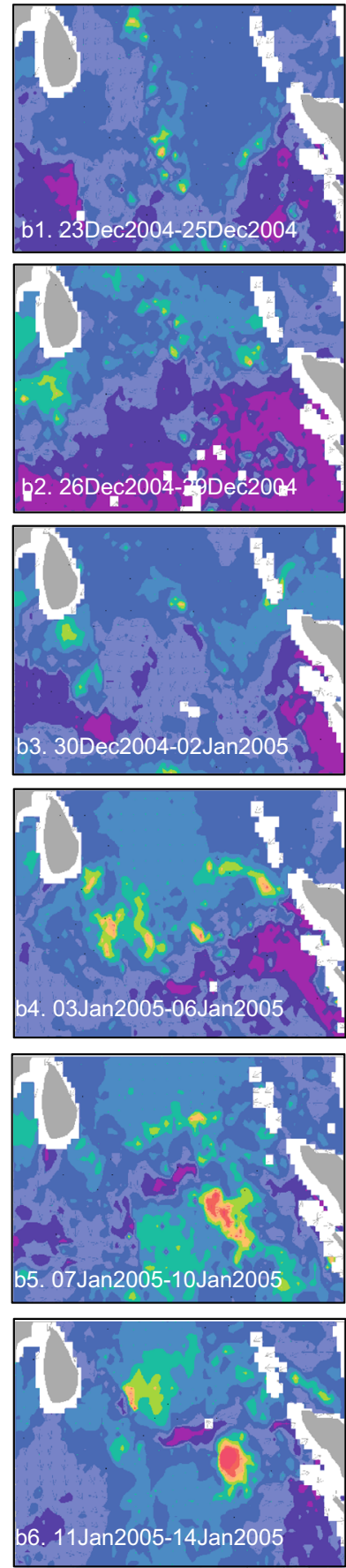

(c) TRMM Rain
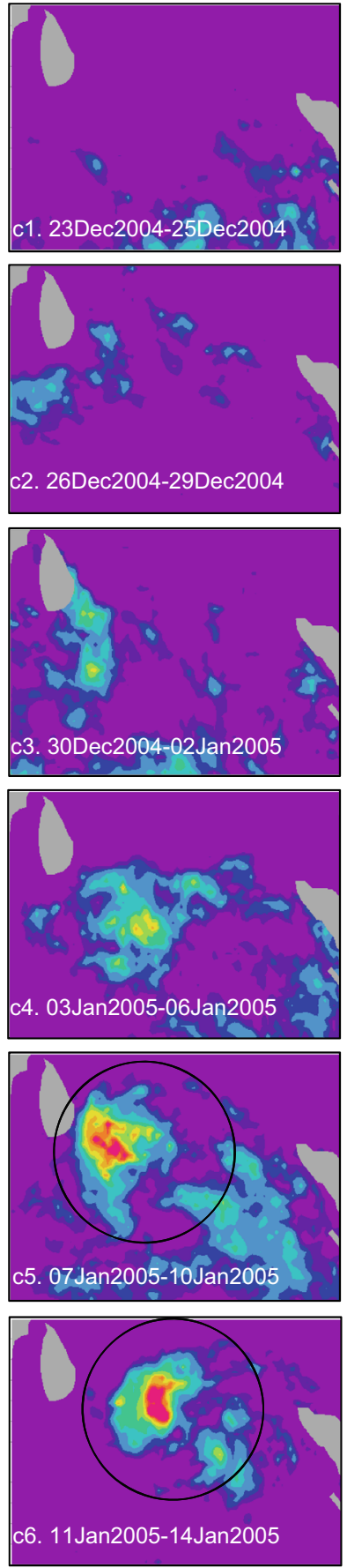

Fig. 2 Distributions of 4-day averaged (a1-a10) MODIS SST (left panels), (b1-b10) QuickScat wind speeds (central panels), and (c1-c10) TRMM accumulated rainfall (right panels) over the southern Bay of Bengal and adjacent waters in the northern Indian Ocean $\left(\mathrm{mm} \mathrm{day}^{-1}\right)$.

the second 4-day period (Fig. 3b) and nearly westward over the southern part and approximately northward over the northern part of the SWE during the third 4-day period (Fig. 3c). This explains the dynamic process for the northward spreading of warm surface waters shown in Fig. 2a3. By comparison, the SSTs over the area to the southeast of Sri Lanka (SES)
Light gray areas represent land points. Black areas in (a1-a10) represent missing MODIS data due to cloud coverage. White areas in (b1-b10) represent unavailable QuickScat data over shallow coastal waters

decreased in the first 4 days (26-29 December, Fig. 2a2) after the tsunami and then gradually increased in the next 4-day period (from 30 December to 2 January, Fig. 2a3), due again to the northwestward advection of warmer surface water from the SWE area. The large-scale SST over the southern BoB (i.e., the northern part of the study region) remained relatively 

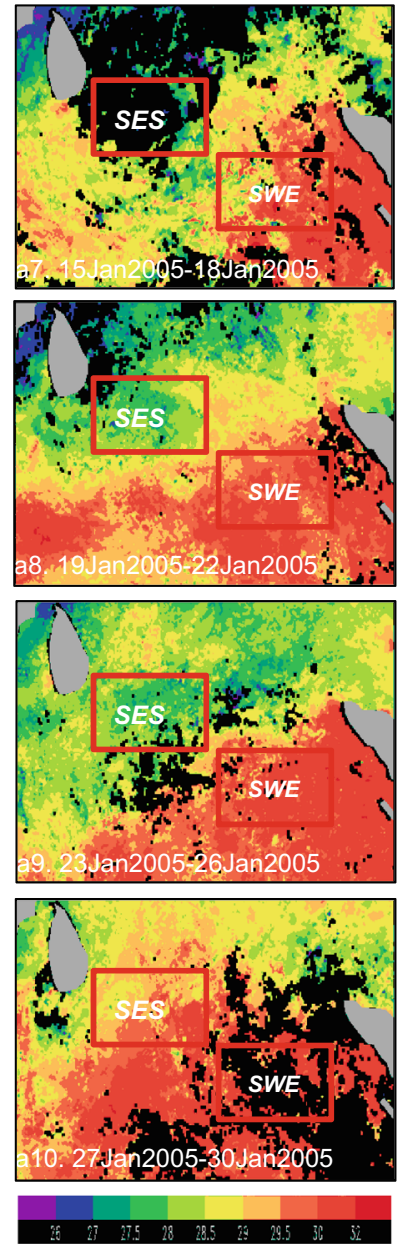

$\left({ }^{\circ} \mathrm{C}\right)$
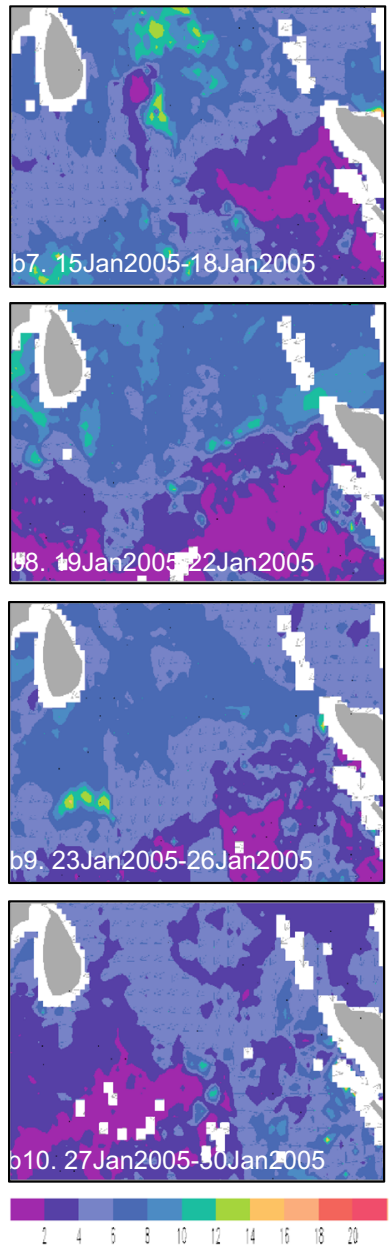

$\left(\mathrm{m} \mathrm{s}^{-1}\right)$
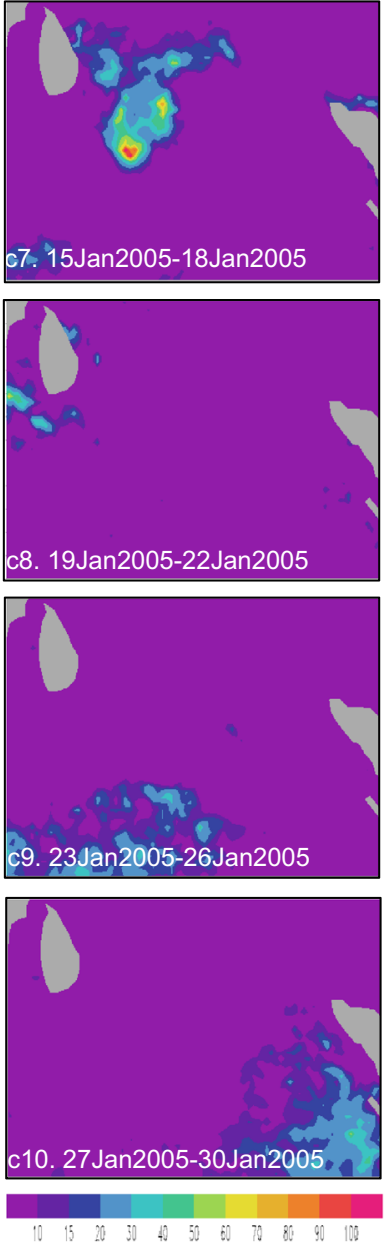

$\left(\mathrm{mm}\right.$ day $\left.^{-1}\right)$

Fig. 2 (continued)

unchanged during these two periods (from 26 December to 2 January).

The MODIS SST data during the fouth and fifth periods (3-10 January) are not available over most of the study region due to heavy cloud cover (Fig. 2a4-5). As mentioned earlier, there was a tropical storm occurring over the SES area during the fifth period. An examination of available MODIS SST data over some isolated areas during these two periods shown in Fig. 2a4-5, together with the MODIS SST data in the sixth period (11-14 January, Fig. 2a6), indicates that the SSTs over the SWE area decreased gradually during these three periods from 3 to 14 January over this area. The simulated SSTs taken from the HYCOM+NCODA global ocean reanalysis also exhibit similar gradual cooling of surface waters over the SWE area during these three periods (Fig. $3 \mathrm{~d}-\mathrm{f}$ ).

The SST distributions during the seventh period (15-18 January, Fig. 2a7) are characterized by relatively warmer surface waters from the west cost of Sumatra Island to the SWE area and relatively cold from the western part of the southern BoB to the south of the SES area (Fig. 2a7). During this period, the SSTs were relatively low over coastal and shelf waters to the east and southeast of Sri Lanka, due mostly to the southward advection of cold surface waters from the western part of the southern BoB, as supported by the simulated sea surface currents taken from the HYCOM+NCODA reanalysis (not shown). It should be noted that a relatively strong tropical cyclone occurred over the area to the east of Sri Lanka during this period. The SSTs were higher over the whole study region in the eight period (19-22 January), except for surface waters to the south of Sri Lanka. There was a cold water tongue during this period, which extended southeastward from coastal waters of Sri Lanka to the SES area.

During the ninth period (27-30 January, Fig. 2a9), the relatively cold surface waters spread over the northern part of the study region, including the Indian Ocean waters around Sri Lanka, except for several isolated areas around Sri Lanka where the SSTs were comparably warmer than adjacent surface waters. During the tenth period (27-30 January, Fig. 2a10), the SSTs were warmer over the study region, particularly for surface waters over the northwestern part of the study region. 
(a) 22 - 25 Dec

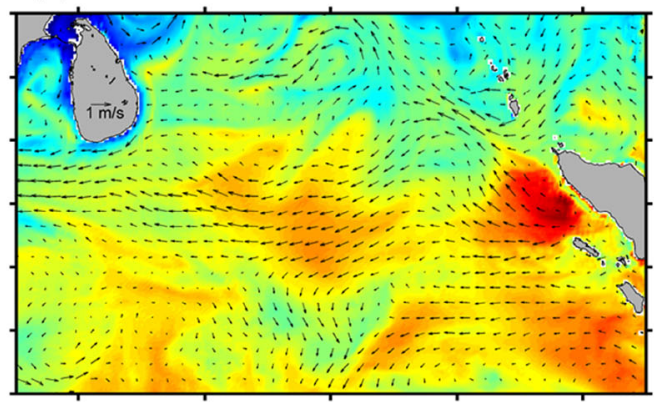

(c) 30 Dec - 2 Jan

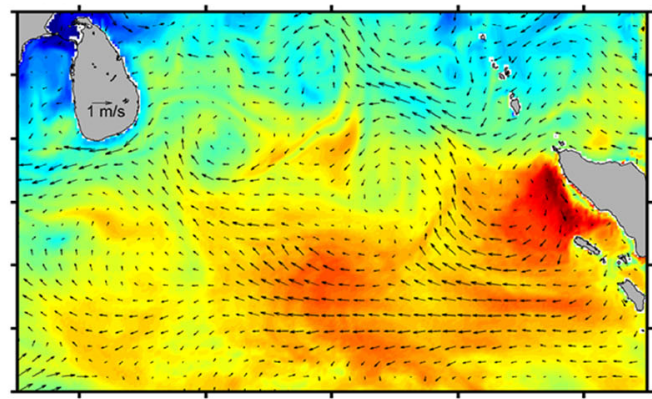

(e) 7 - 10 Jan

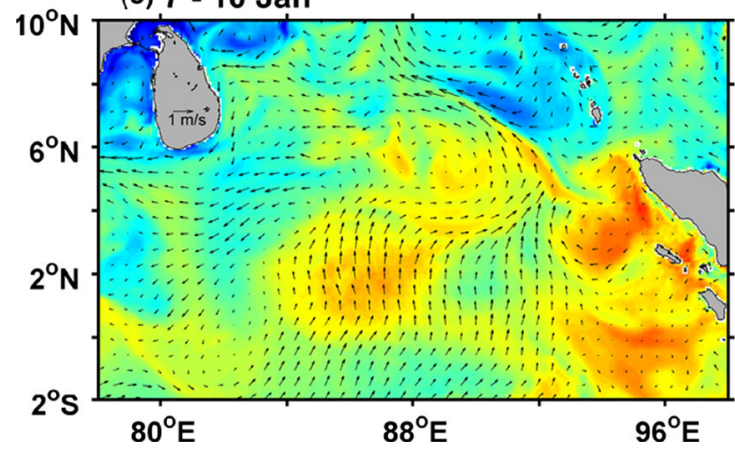

(b) 26 - $29 \mathrm{Dec}$

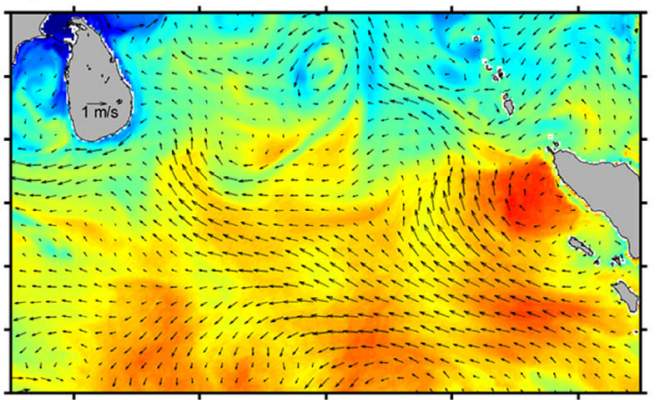

(d) 3 - 6 Jan

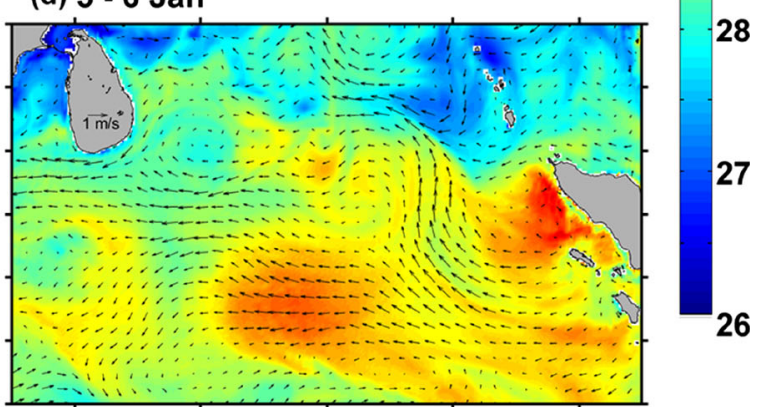

(f) 11 - 14 Jan

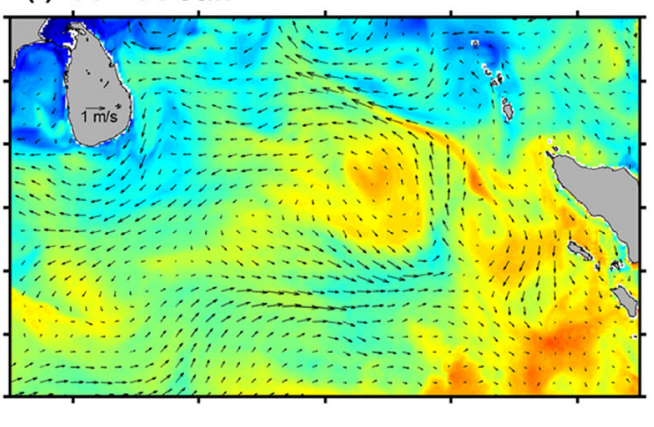

Fig. 3 Distributions of 4-day averaged ocean currents and water temperatures at the sea surface calculated from three hourly simulated fields extracted from the HYCOM+NCODA global ocean reanalysis

Figure 4a presents time-series of 4-day means of SSTs and air temperatures at the sea surface averaged from the MODIS SST data and the NCEP atmospheric temperatures over the small area to the south of Sri Lanka (marked by a box in Fig. 1). The time-series shown in Fig. $4 \mathrm{a}$ indicates that the area-average SSTs and air temperatures at the sea surface had different temporal variability before the tsunami but showed similar temporal changes after the tsunami, particularly after 30 December 2004. The SST over the SWE area gradually decreased from 26 December to 7 January and then increased with time during the period of 15-26 January. The 4-day mean SSTs and air temperatures restored to the pretsunami levels in the tenth period (27-30 January, Fig. 2a10, Fig. 4). It should be noted that time-series of the 4-day mean fields shown in Fig. 4 exclude any temporal variability of periods less than 4 days.
A natural question raised is whether the SST changes after the tsunami shown in Figs. 2 and 4 were part of normal seasonal variations of the SST in the region. To address this issue, we calculated the monthly mean SST anomalies (Fig. 5a) from the MODIS SSTs by eliminating the 10-year (1999-2008) averaged (monthly mean) SSTs from the monthly mean SSTs of each year at each grid point of the satellite data. The monthly mean SST anomalies over the SES area were positive in December 2004 but negative in January 2005 (Fig. 5a), indicating that surface waters over the SES area were abnormally warm in December 2004 and abnormally cool in January 2005 in comparison with the normal SST conditions over this area in the 10-year period 1999-2008. In the SWE area, the monthly mean SST anomalies were both positive in December 2004 and January 2005 (Fig. 5a), indicating that surface waters over this area were abnormally warm in these two months. 
Fig. 4 Time-series of 4-day means of a MODIS SST and air temperature $\left({ }^{\circ} \mathrm{C}\right), \mathbf{b}$ LHF and SHF $\left(\mathrm{W} \mathrm{m}^{-2}\right)$, c relative humidity $(\%)$ and sea level pressure $(\mathrm{kPa})$, and d QuickScat wind $\left(\mathrm{m} \mathrm{s}^{-1}\right)$ and TRMM rainfall $\left(\mathrm{mm} \mathrm{day}^{-1}\right)$ over the area to the southeast of Sri Lanka (marked by the solid box in Fig. 1) from 20 November 2004 to 30 January 2005. The red vertical line indicates the time of the 2004 Indian Ocean tsunami

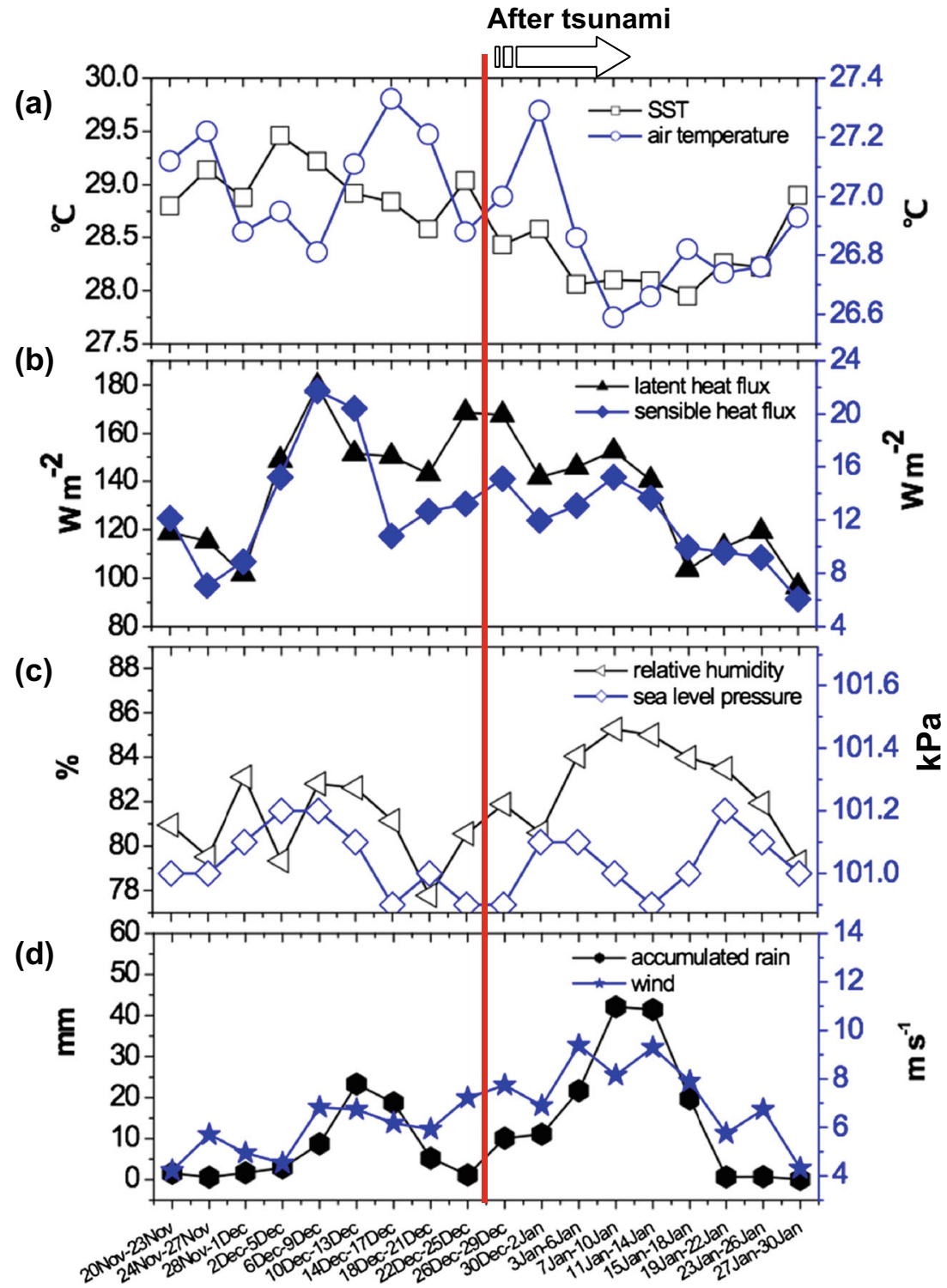

\subsection{Changes in wind and accumulated rainfall}

The QuickScat winds in the first 8 days after the tsunami (26 December 2004 to 2 January 2005) were relatively weak and less than $10 \mathrm{~m} \mathrm{~s}^{-1}$ in the study region except for several local areas (Fig. 2b2-3). In comparison with the pre-tsunami surface winds in the period of 23-25 December (Fig. 2b1), the 4-day mean surface winds during the first 8-day period after the tsunami seem not to be affected significantly by the tsunami.

During the period of 3-6 January (Fig. 2b4), the 4-day mean surface winds were also relatively weak over the southern and northern parts of the study region but relatively strong over several local areas in the central part of the study region with the 4-day mean wind speeds up to $18 \mathrm{~m} \mathrm{~s}^{-1}$. The 4-day surface winds in the period of 7-18 January (Fig. 2b5-7) were strong over the SWE, SES, and adjacent areas, with the maximum 4-day mean wind speeds up to $20 \mathrm{~m} \mathrm{~s}^{-1}$. As mentioned earlier, two tropical cyclones (Fig. 1) swept the offshore areas to the southeast of Sri Lanka with a weak cyclone in 8-10 January (Unisys 1) following by a strong cyclone in 14-17 January (Unisys 2), 2005. These two cyclones resulted in relatively strong time-mean surface winds over the SES and adjacent waters during these three periods. By comparison, the time-mean winds were weak during the next three 4-day periods of 19-30 January in the study region except for areas around Sri Lanka and several isolated deep waters to the south of Sri Lanka (Fig. 2b8-10).

The 4-day averaged accumulated rainfall estimated from the TRMM data was small in the pre-tsunami period of 23 25 December (Fig. 2c1). By comparison, the 4-day averaged accumulated rainfall increased moderately in the offshore 


\section{Dec2004}
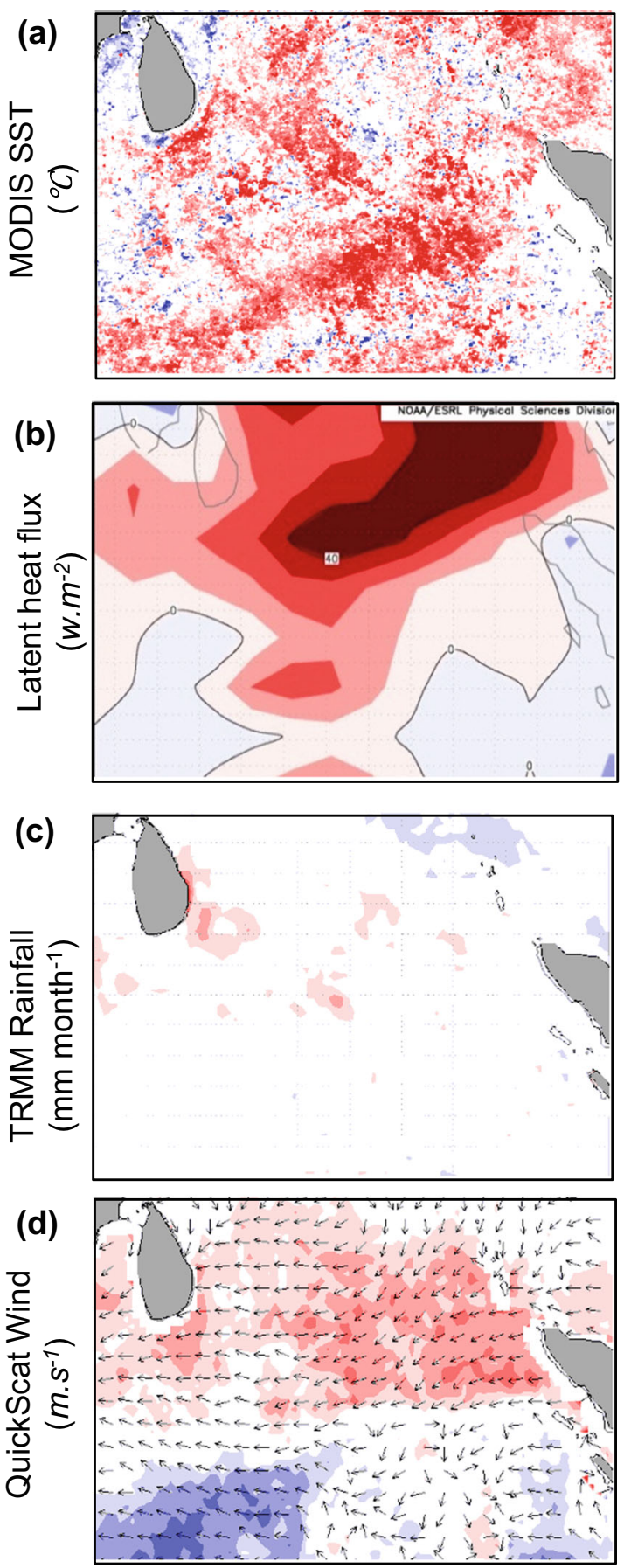

Fig. 5 Distributions of monthly mean anomalies relative to the 10-year (1999-2008) mean of a MODIS SST $\left({ }^{\circ} \mathrm{C}\right)$, b latent heat flux $\left(\mathrm{W} \mathrm{m}^{-2}\right), \mathbf{c}$ TRMM rainfall $\left(\mathrm{mm} \mathrm{month}{ }^{-1}\right)$, and $\mathbf{d}$ QuickScat wind $\left(\mathrm{m} \mathrm{s}^{-1}\right)$ in

waters to the southwest of Sri Lanka during the first 4 days after the tsunami (26-29 December, Fig. 2c2). The rainfall increased in the deep waters to the south of the Sri Lanka during the period from 30 December to 2 January (Fig. 2c3),

\section{Jan2005}
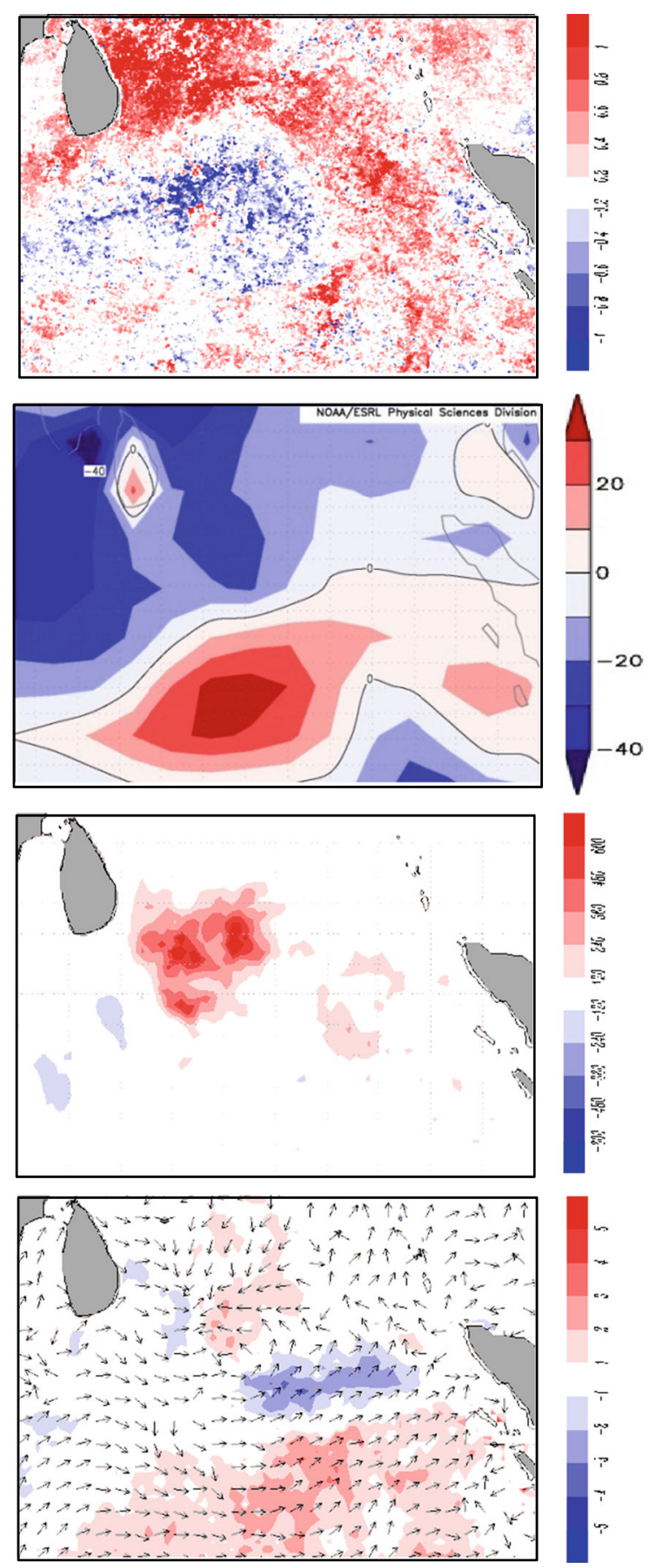

December 2004 (left panels) and January 2005 (right panels). The color image and arrows in $\mathbf{d}$ represent amplitudes and directions of monthly mean wind velocity anomalies

with the maximum accumulated rainfall of about $60 \mathrm{~mm}$ day $^{-1}$. The accumulated rainfall and the high rainfall areas increased in the following 12 days (Fig. 2c4-6) with the highest rainfall of $\sim 110 \mathrm{~mm} \mathrm{day}^{-1}$ occurred in the area to the 
south of Sri Lanka during 11-14 January 2005 (Fig. 2c6). Figure $4 \mathrm{~d}$ shows the post-tsunami increase in the 4-day averaged accumulated rainfall and wind speeds over the local area to the south of Sri Lanka in the first 16 days after the Indian Ocean tsunami.

To demonstrate abnormal rainfalls after the tsunami over the study region, we calculated the 4-day averaged cumulative rainfall anomalies from TRMM precipitation data by eliminating the 10-year (1999-2008) averaged (4-day mean cumulative) rainfalls from the 4-day mean cumulative rainfalls of each year. Figure 6 demonstrates that the 4-day averaged accumulated rainfall anomalies were positive over the SES area and adjacent offshore waters in the period of 3-6 January with a maximum anomaly up to $70 \mathrm{~mm}$ day $^{-1}$. (The physical explanation for the positive rainfall anomalies after the tsunami will be given in section 4.2). The positive 4-day averaged rainfall anomalies moved eastward in the period 7-10 January (Fig. 6b). The positive rainfall anomalies became weaker in the period 11-14 January (Fig. 6c). In addition, Fig. $5 \mathrm{c}$ demonstrates that the monthly mean accumulated rainfall in January 2005 was higher by about $600 \mathrm{~mm}$ month $^{-1}$ than the 10 -year mean monthly data over the offshore area to the southeast of Sri Lanka (the area marked by "a" in Fig. 1).

\subsection{Changes in the heat flux, relative humidity, and sea level air pressure}

Time-series of changes in the LHF and SHF, relative humidity, and sea level pressure in the offshore area to the southwest of Sri Lanka (the area marked by "a" in Fig. 1) from 20 November 2004 to 30 January 2005 are shown in Fig. 4b-c. The 4-day averaged LHF and SHF of this area had highly similar temporal variability during this 30 -day period, with a large decreasing (negative) trend after the Indian Ocean tsunami (Fig. 4b). It should be noted that the 4-day averaged LHF and SHF became relatively large during the tsunami, which is consistent with the previous findings. Based on the TropFlux dataset, Vishnu et al. (2012) demonstrated that the latent heat flux increases abnormally in most of areas in the Bay of Bengal and adjacent Arabian Sea during the 2004 Indian Ocean tsunami.

The 4-day averaged monthly anomalies of LHF presented in Fig. 5b demonstrate that the LHF decreased in January 2005 in the study region, except for deep waters over the southern part of the study region. In particular, the deep waters around Sri Lanka experienced reduction in the LHF after the tsunami (Fig. 5b).

The changes of relative air humidity at the sea surface in the local area to the southwest of Sri Lanka had similar temporal variability as the rainfall and surface winds after

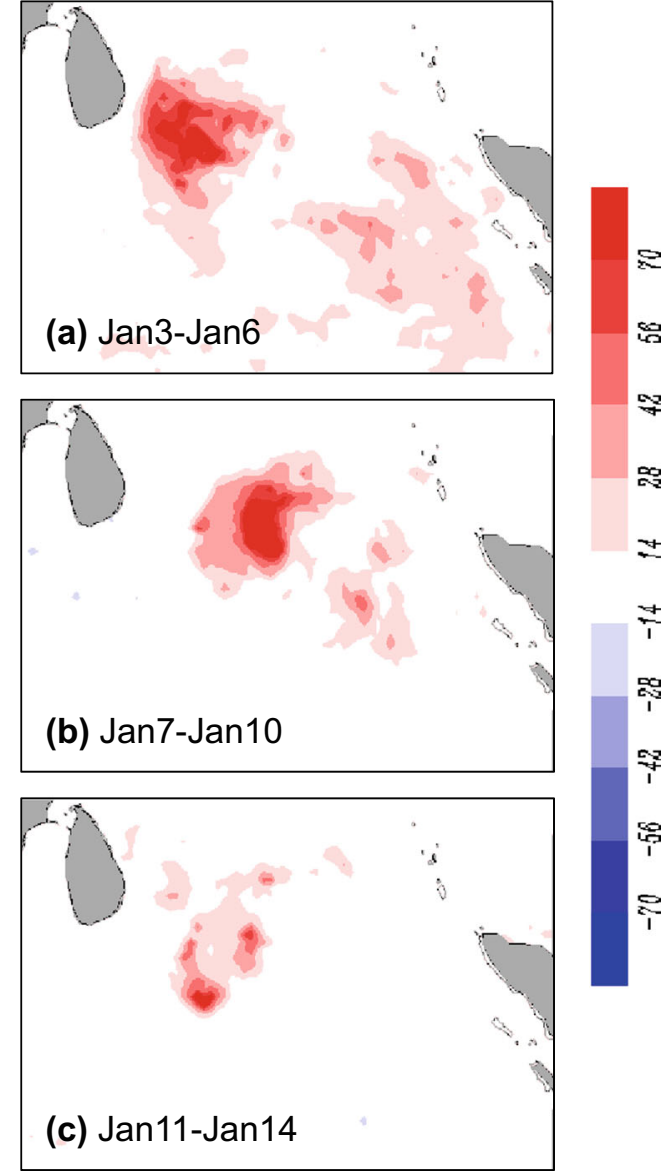

Fig. 6 Distributions of the 4-day mean anomalies $\left(\mathrm{mm} \mathrm{day}^{-1}\right)$ relative to the 10-year (1999-2008) mean of TRMM rainfalls during periods of a 36 January, b 7-10 January, and c 11-14 January after the 2004 Indian Ocean tsunami

the tsunami, with an increase during the period of 7-14 January 2005 (Fig. 4c-d). By comparison, the sea level air pressure in the same local area had out-of-phase variability in time with the relative humidity, rainfall, and surface winds, which decreased in time during the period of 6-14 January and reached the minimum during the period of 11-14 January 2005 (Fig. 4c).

\subsection{Changes in sea level anomaly}

Figure 7 presents the longitude-time and latitude-time Hovmoller plots of Ssalto/Duacs SLA during the period of 15 December 2004 to 15 January 2005. The longitudinal and latitudinal transects are marked respectively in the upper right and lower right panels in Fig. 7. The longitudinal transect is at $3.4^{\circ} \mathrm{N}$ (Fig. 7a), which is approximately the latitudinal position of the epicenter of the earthquake $\left(95.854^{\circ} \mathrm{E}, 3.316^{\circ} \mathrm{N}\right)$. The latitudinal transect is at $87.9^{\circ} \mathrm{E}$ (Fig. $7 \mathrm{~b}$ ). The time-dependent SLA along the longitudinal transect during this period has a similar distribution, which was higher over the eastern part and 
LATTUDE : $3.4 \mathrm{~N}$

YE,AR : 2014

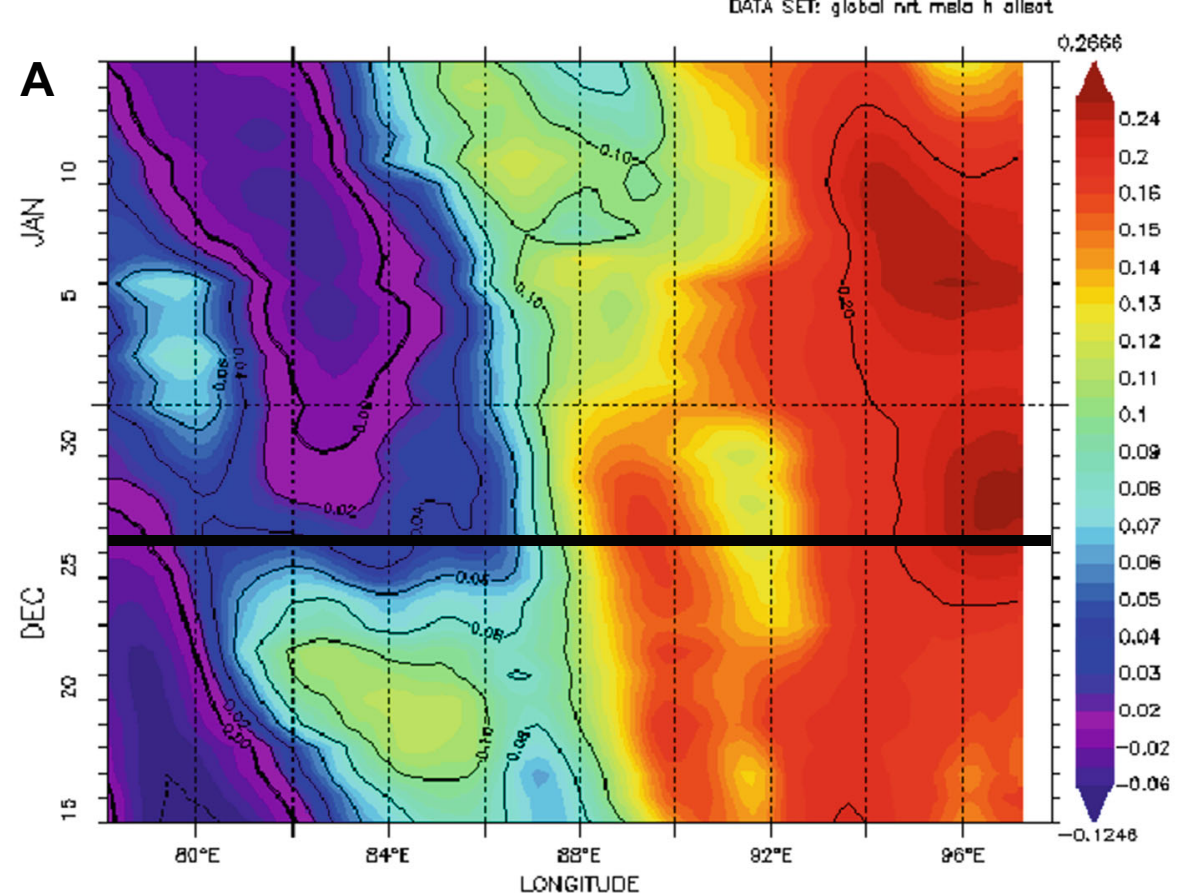

LONGITJDE $=87.9 E$ YEAR : 2014
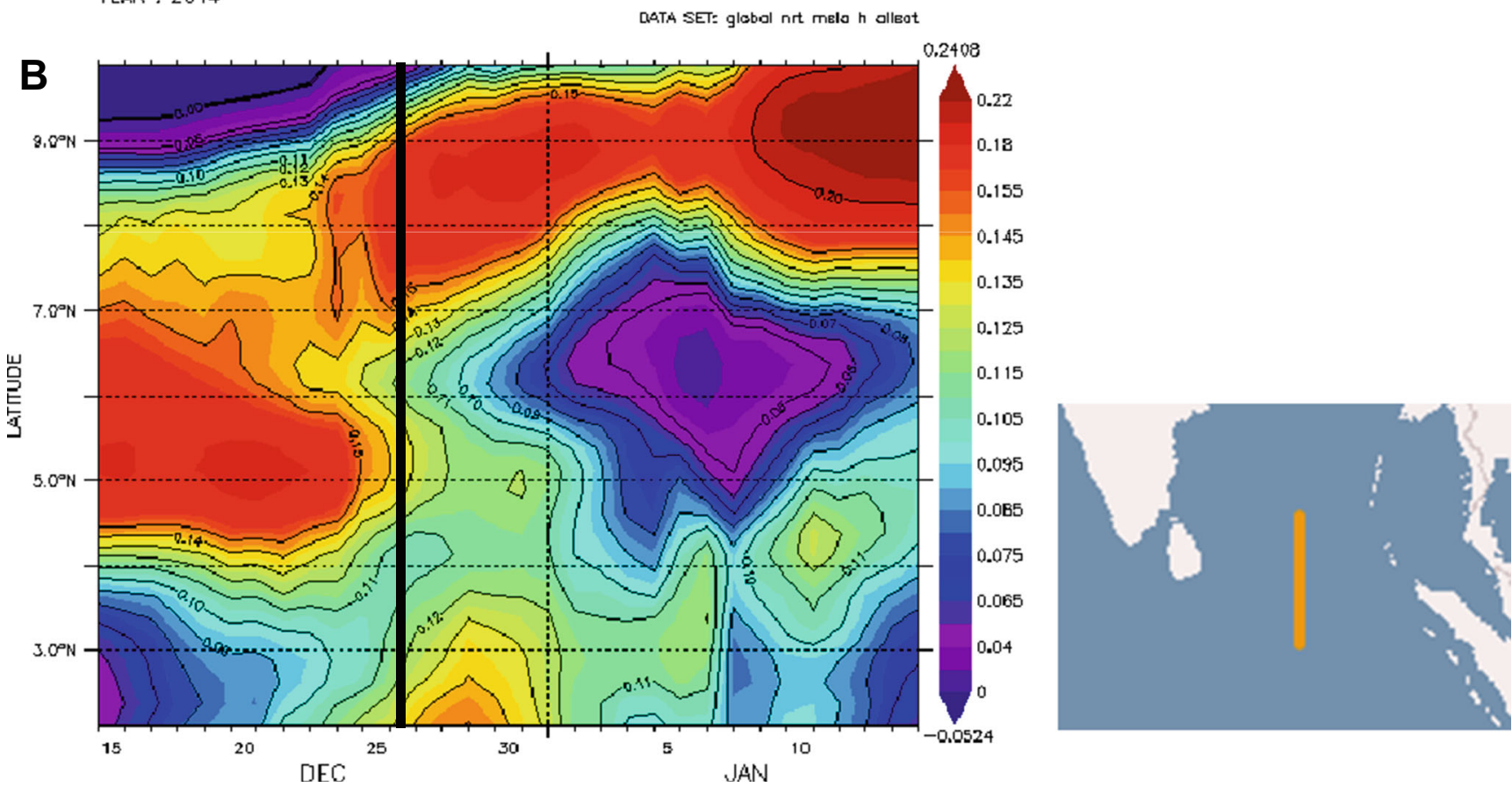

Fig. 7 a Longitude-time and b latitude-time Hovmoller plots of Ssalto/ Duacs sea level anomaly (SLA) from the period of 15 December 2004 to 15 January 2005. The black line indicates the onset of the earthquake.

lower over the western part of the transect (Fig. 7a). It is worthwhile to note that the SLA over the SES area, although lower than the counterpart to the east before the tsunami, was positive before the tsunami and became negative sooner after the tsunami (Fig. 7a). Along the
Right panels show respectively the longitude and latitude positions of transects for the Hovmoller plots

latitudinal transect, the time-dependent SLA was positive over the central part $\left(4^{\circ} \mathrm{N}-7^{\circ} \mathrm{N}\right)$ and negative over the southern and northern part of the transect before the tsunami, and the pattern was reversed after the tsunami (Fig. 7b). 


\section{Discussion}

\subsection{Relationships between SST and LHF}

It was suggested that the large vertical displacement and propagation of the 2004 Indian Ocean tsunami waves resulted in strong vertical mixing, which brought subsurface cold waters to the surface layer and generated SST cooling over the earthquake hypocenter and adjacent regions of the fault area (Chakravarty 2006). The influences of the Indian Ocean tsunami on the post-tsunami SST changes in the northern Indian Ocean were investigated in the past but with different findings (Murthy 2005; Agarwal et al. 2007; Luis et al. 2007). An increase of SST with $1{ }^{\circ} \mathrm{C}$ was found in the coastal water off Chennai of India in the mid of January 2005 (Murthy 2005). On the other hand, SST cooling (about $0.5^{\circ} \mathrm{C}$ ) after the tsunami was reported near Andaman and Nicobar Islands during the period 21-27 December 2004 (Agarwal et al. 2007). It was suggested that the SST cooling around Andaman Island might attribute to the westward geostrophic flow from the Andaman Sea facilitated by a sea surface height gradient after the tsuna$\mathrm{mi}$ (Luis et al. 2007). In situ observations from 18 January to 17 February 2005 demonstrated that the SST increased in the vicinity of Andaman Island but decreased near the coast of Chennai (Luis et al. 2007). Based on the satellite remote sensing data, we demonstrated in this study that the SST increased (about $1-4^{\circ} \mathrm{C}$ ) in the southern BoB and adjacent deep waters of the northern Indian Ocean after the tsunami from 26 December 2004 to 2 January 2005 (Fig. 2a2-3). There are two plausible reasons for the post-tsunami SST changes in the study region. One plausible reason is the westward advection of relatively warm surface waters carried by the westward flow from the Andaman Sea due to the seasonal Rossby waves forced by the Indian Ocean monsoon (Yang et al. 1998). This westward advection was supported by the simulated ocean surface currents taken from the HYCOM-NCODA global ocean reanalysis, although it is unclear how much the westward advection over the study region produced by the dataassimilative HYCOM-NCODA is affected by the additional sea surface height change associated with the tsunami. The other plausible reason is that SST warming during this period was caused by the solar heating due to the rain-free weather conditions during the first 8 days after the tsunami. It should be noted that the SST in the study region decreased after 2 January 2005 , particularly over the offshore area to the southeast of Sri Lanka (SES), which was due most likely to the temperature reduction by the windy and rainy weather conditions in mid-January 2005.

The latent heat flux plays a very important role in affecting the energy budget at the sea surface. Both the SST and sea surface winds are closely correlated with the latent heat flux, particularly in the equatorial and tropical oceans (Zhang and Mcphaden 1995). The evaporation rate is directly proportional to the ocean's latent heat loss and is affected by the oceanatmosphere temperature difference (Siedler et al. 2001). The higher the sea surface temperature is than the sea surface air temperature, the more flux of sensible and latent heat releases to the atmosphere from the ocean surface (Bjerknes 1966). Usually, the LHF increases with wind speeds and vice versa. But, the increase of SST not always leads to the increasing of LHF (Liu 1988; Sui et al. 1991; Zhang and Mcphaden 1995). It was demonstrated in this study that the post-tsunami LHF decreased over the ocean waters to the southeast of Sri Lanka (SES) but increased in the offshore waters to the southwest of epicenter (SWE) (Fig. 5b). The increase of LHF in the SWE area is consistent with the QuickScat winds over the same area during the period of 3-14 January 2005, which implies that there should be a causal relation between these two atmospheric variables.

The SST over the SWE area also underwent a short-term increasing shortly after the tsunami (from 26 December 2004 to 2 January 2005). But after this period, the SST over this area kept decreasing accompanied by notably increasing of accumulated rainfall and wind magnitude. Cloudy weather conditions in the rainy days in January over this region should facilitate the decreasing of SST. After this period and till the end of January, due to the clearance of wind and rain, the SST in this region increased gradually from 28 to $32{ }^{\circ} \mathrm{C}$ (Fig. 2a). The increasing of SST in the SWE area may lead to high evaporation rates. As a result, the LHF in the SWE area increased in January 2005 (Fig. 5b). A noticeable increase in the LHF was also reported by Agarwal et al. (2007). They found an apparent growth in the water vapor loading in the Tropical Rainfall Measuring Mission/Microwave Imager (TMI) data from 31 December 2004 to 11 January 2005 near Andaman and Nicobar Islands. They suggested, however, that the increased water vapor loading in the atmosphere following the tsunami is not due to winds or the increase in SST but possibly due to the direct injection of water into the atmosphere.

\subsection{Succession relationship between the changes of SST, accumulated rainfall, and wind}

Of all the atmospheric and oceanographic variables considered in this study, the rainfall and SST had noticeable increases in comparison with their 10-year means between 1999 and 2008. The important question to be addressed is what are the main dynamic processes affecting the changes in these variables within 1 month after the tsunami. Considering a huge disturbance of the tsunami to the ocean water, one possible driver for the serial changes may attribute to the change in SST. The SST over the SWE area increased about $1-4{ }^{\circ} \mathrm{C}$ within 4 days after the tsunami, which should enhance the heat and water vapor transfer to the lower troposphere that was thereby destabilized. Concurrently, surface easterlies over this area weakened or even reversed and 
rainfall increased. With the diminished upwelling, further surface heating led through a feedback process to even more rain (Ichiye and Petersen 1963). Increasing of SST might also increase deep convection and produced extensive optically thick cirrus cloud, which blocked the solar radiation from reaching the surface of the ocean and further cooling of the ocean (Ramanathan and Collins 1991). Positive correlations between rainfall and SST for the period of July to September in the eastern equatorial Atlantic was found by OpokuAnkomah and Cordery (1994). They also found lagged correlations between the SSTs in May to July and rainfall from July to September. A possibility also remains that higher SST could somehow modify the moisture and thermal distribution of the overlying air to produce more local rainfall during the study period.

The succession changes of these oceanographic conditions and atmospheric variables after the tsunami suggested that they might conceive as an interrelated system. Shortly after this tsunami, the longitudinal sea level height difference increased over the SES area (Fig. 7a), which led to the supplement of warm surface waters from the Andaman Sea and the Southern Indian Ocean. The incoming warm water due mainly to the northwestward surface currents combined with the solar heating increased the surface temperature of the SWE within in the first few days after the tsunami (increased abnormally about $1-4{ }^{\circ} \mathrm{C}$ in contrast with its historical 10 -year mean value). With the increasing of SST, latent and sensible heat flux both increased over the SWE area, and SST increased the enhanced convective activity, the ensuing westward wind, and accumulated rainfall enhanced after the decreasing of surface pressure. The abnormal increase of wind magnitude was observed, and its strength kept increasing during the period of 7-14 January. In addition, during the period of 7-10 January, the wind was strong and an abnormal increase of rainfall was observed, of which the strength decreased with the time prolonging to 18 January, 2005. With the retreat of the rainfall (15-18 January), an abnormally high chlorophyll plume with the ribbon shape was found in the area in the period 19-20 January, and the chlorophyll concentration decreased with the time and its position also drifted westerly for some distance (Tang et al. 2008). The SST, rainfall, and winds seem to have a lead-lag relationship, as the start of abnormally high wind speeds and dense rainfall were all lag about 8-12 days after the increase of SST. There were several studies that discussed the relations between SST and rainfall (Opoku-Ankomah and Cordery 1994; Wang 2006). Positive correlations between rainfall and SST for the period July to September in the eastern equatorial Atlantic was found by Opoku-Ankomah and Cordery (1994). They also found the lagged correlations between the SSTs from May to July and rainfall from July to September. It should be noted, however, that a firm understanding of local changes in the atmospheric and oceanographic conditions in the southern BoB after the 2004 Indian
Ocean tsunami requires a numerical modeling study using a coupled atmosphere-ocean model, which is beyond the scope of this study.

Acknowledgments This work was jointed supported by the National Natural Science Foundation of China (Key Project 41430968 and 40576053), the China Petroleum \& Chemical Corporation (313099), and program of Collaborative Innovation Center for 21st-Century Maritime Silk Road Studies awarded to Danling Tang and Visiting Fellowship Program of State Key Laboratory of Tropical Oceanography awarded to JY Sheng. The authors thank Dr. Gad Levy and two anonymous reviewers for providing valuable comments and suggestions.

Open Access This article is distributed under the terms of the Creative Commons Attribution 4.0 International License (http:// creativecommons.org/licenses/by/4.0/), which permits unrestricted use, distribution, and reproduction in any medium, provided you give appropriate credit to the original author(s) and the source, provide a link to the Creative Commons license, and indicate if changes were made.

\section{References}

Agarwal VK, Sharma AMR, Agarwal N, Parekh A (2007) A study of airsea interaction following the tsunami of 26 December 2004 in the eastern Indian Ocean. Int J Remote Sens 28:3113-3119

Anilkumar N, Sarma YVB, Babul KN, Sudhakar M, Pandey PC (2006) Post-tsunami oceanographic conditions in southern Arabian Sea and Bay of Bengal. Curr Sci 90:421-427

Bjerknes J (1966) A possible response of the atmospheric Hadley circulation to equatorial anomalies of ocean temperature. Tellus 18:820 829

Chakravarty SC (2006) The Sumatra-Andaman earthquake driven sea surface temperature and wind anomalies. 36th COSPAR Scientific Assembly. Beijing, China, p 276

DOD (2005) Preliminary assessment of impact of tsunami in selected coastal areas of India. Department of ccean development, integrated coastal and marine area management project directorate, Chennai, $58 \mathrm{pp}$

Godin OA (2004) Air-sea interaction and feasibility of tsunami detection in the open ocean. J Geophys Res 109:C05002.1-C05002.20

Ichiye T, Petersen JR (1963) The anomalous rainfall of the 1957-58 winter in the equatorial central Pacific arid area. J Meteor Soc Jpn 41:172-182

Kumar B, Chakraborty A (2011) Movement of seasonal eddies and its relation with cyclonic heat potential and cyclogeneisis points in the Bay of Bengal. Nat Hazards 59:1671-1689

Lay T, Kanamori H, Ammon CJ, Nettles M, Ward SN, Aster RC, Beck SL, Bilek SL, Brudzinski MR, Butler R, DeShon HR, Ekstr G, Satake K, Sipkin S (2005) The Great Sumatra-Andaman Earthquake of 26 December 2004. Science 308:1127-1133

Liu WT (1988) Moisture and latent heat flux variabilities in the tropical Pacific derived from satellite data. J Geophys Res 93:6749-6760

Luis AJ, Pednekar SM, Sudhakar M (2007) Post-tsunami impact study on thermohaline structure in the Bay of Bengal. Curr Sci 93:699-703

Murthy KSR (2005) First oceanographic expedition to survey the impact of the Sumatra earthquake and the tsunami of 26 December 2004. Curr Sci 88:1038-1039

Opoku-Ankomah Y, Cordery I (1994) Atlantic sea surface temperatures and rainfall variability in Ghana. J Clim 7:551-558

Paul S, Chakraborty A, Pandey PC, Basu S, Satsangi SK, Ravichandran M (2009) Numerical simulation of Bay of Bengal circulation features from ocean general circulation model. Mar Geod 32:1-18 
Potemra JT, Luther ME, O'Brien J (1991) The seasonal circulation of the upper ocean in the Bay of Bengal. J Geophys Res 96:12,667-12,683

Ramanathan V, Collins W (1991) Thermodynamic regulation of ocean warming by cirrus clouds deduced from observations of the $1987 \mathrm{El}$ Nino. Nature 351:27-32

Sarma KVLNS, Ramana MV, Subrahmanyam V, Krishnal KS, Ramprasad T, Desa M (2000) Morphological features of the Bay of Bengal. J Ind Geophys Union 4:185-190

Siedler G, Church J, Gould J (Eds.) (2001) Ocean circulation and climate - observing and modeling the global ocean. (Volume 77 in the International Geophysics Series), Academic Press, London. Section 1: the ocean and climate, 3-43

Singh RP, Cervone G, Kafatos M, Prasad AK, Sahoo AK, Sun D, Tang DL, Yang R (2007) Multi-sensor studies of the Sumatra earthquake and tsunami of 26 December 2004. Int J Remote Sens 28:28852896

Sui CH, Lau KM, Betts AK (1991) An equilibrium model for the coupled ocean-atmosphere boundary layer in the tropics. J Geophys Res 96: 3151-3163

Tang DL, Satyanarayana B, Zhao H, Sing PR (2006) A preliminary analysis of the influence of Sumatra Tsunami on Indian Ocean chlorophyll-a and SST. Adv Geosci 5:15-20

Tang DL, Zhao H, Satyanarayana B, Zheng GM, Singh RP, Lv JH (2008) Enhancement of chlorophyll-a in the northeastern Indian Ocean after the 2004 South Asian Tsunami. Int J Remote Sens 30:4553-4565
Thurman HV, Trujillo AP (2002) Essentials of oceanography, 7th edn. Prentice Hall, Upper Saddle River, 524 pp

Titov V, Rabinovich AB, Mofjeld HO, Thomson RE, Gonzalez FI (2004) The global reach of the 26 Sumatra Tsunami. Science 309:20452048

UNEP (2005) After the tsunami: Rapid Environmental Assessment. Nairobi: UNEP. $140 \mathrm{pp}$

Vinayachandran PN, Kurian J (2007) Hydrographic observations and model simulation of the Bay of Bengan freshwater plume. DeepSea Res I 54:471-476

Vishnu R, Varikoden H, Anil Kumar V, Murali Das S, Mohan Kumar G, Subi Symon VN (2012) Abnormal modulation of atmospheric parameters during the tsunami of 2004. Curr Sci 102:1575-1580

Wang C (2006) An overlooked feature of tropical climate: inter-PacificAtlantic variability. Geophys Res Lett 33, L12702. doi:10.1029/ 2006GL026324

Yan ZZ, Tang DL (2009) Changes in suspended sediments associated with 2004 Indian Ocean Tsunami. Adv Space Res 43:89-95

Yang J, Yu L, Koblinsky CJ, Adamec D (1998) Dynamics of seasonal variations in the Indian Ocean from TOPEX/POSEIDON sea surface height and an ocean model. Geophys Res Lett 25:1915-1918

Zhang GJ, Mcphaden MJ (1995) The relationship between sea surface temperature and latent heat flux in the equatorial pacific. J Clim 8: 589-605 